\title{
Human Capital and Economic Growth of Pakistan
}

\begin{abstract}
Ahad Hassan Afridi ${ }^{1}$
Abstract

Human capital consists of set of resources which define individuals' overall ability and includes skills, education, training, health and other talents. These abilities collectively shape up the potential of citizens of a country and help in charting the course of economic growth and development of that country. The ranking of Pakistan in terms of human capital index is reported to have dropped to 113 from 109 out of 124 countries (Human Capital Report 2014-2015) and thus requires a lot of attention. The main aim of this paper is to investigate the relationship between human capital and economic growth in Pakistan. Explaining human capital by the proxies of primary enrolments rate, birth rate, and infant mortality rate, this paper confirms the role of human capital in promoting development in Pakistan. Physical capital was used as a fixed capital and one of the factors of production. Result indicates that the two main sectors which need considerable amount of attention are education and health. This objective can be achieved by allocating high percentage of GDP to these sectors.
\end{abstract}

Keywords: Human Capital, economic growth, Pakistan

\section{Introduction}

There is a consensus among economists that countries with more natural resources have the tendency to develop more as compared to other countries having fewer resources (NRGI Reader). The presence of only these materials does not guarantee an economic growth but human resource shared with other factors result in good economic output. It is proved in different growth theories that human capital always plays its role in development. The most central and important factors in development of human capital are education and health due to their bigger role in the economy. However, there other variables too which contribute towards human capital. In a country's economic growth, human capital plays a very fundamental role as it shows the health of an economy and its people.

In spite of knowing the value of human capital and its effects on growth, there is still no progress or attention given to this important sector. The expenditure on education sector of Pakistan is just 2.3\% of GDP (human developing report, 20072008) which is very low as compared to other neighbouring countries (World Bank report). Every manifestation related to education is near to the ground in Pakistan.

1 Institute of Management Sciences Peshawar, Correspondence concerning this article should be addressed to E-mail: ahad.afridi2@gmail.com 
Similarly, the health sector gets only $2.7 \%$ of GDP (World Bank Report) resulting into poor health conditions nation-wide. This is the reason why Pakistan stands at the top in the list for highest infant mortality rate and other diseases like Polio, Malaria and Tuberculosis.

Figure 1 shows the data of Pakistan's spending on education as a percentage of its GDP from 1998 to 2012. According to World Bank, in 2010 the spending was 2.37\% of the GDP which decreased by $2.2 \%$ and $2.1 \%$ in 2011 and 2012, respectively. The international standard for education allocation is $4 \%$ but still there was no increase in this ratio in Pakistan in 2013 and 2014.

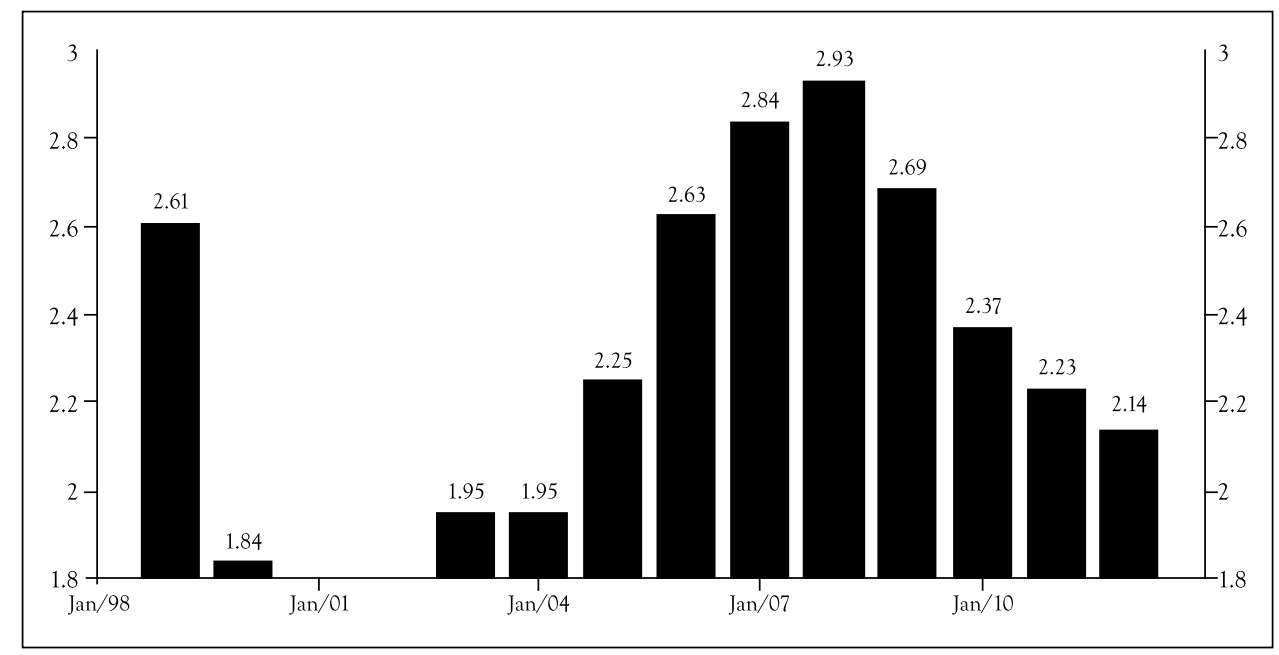

Figure 1: Expenditure on Education from 1998-2012 (Source: World Bank)

The GDP spending on health by government of Pakistan is just 2.7\% (as per 2012 statistics) for such a large population of 184 million (World Bank data, 2013). This less amount of allocation is the reason behind a growing number of diseases such as Polio which is eradicated all around the world but still exists in Pakistan. The services for woman and children are very inefficient and cause several complications during birth. These are the responsibilities of the government to provide proper facilities and control infant mortality rate at a time when it stands highest in the world for Pakistan.

By giving such less attention towards these important sectors, economic growth cannot be achieved. The motive for mentioning the indicators like education, and health is to bring the human capital debate and its impact on economic growth of Pakistan under the attention of policymakers.

\section{Literature Review}

Afzal (2010) in his paper focused on school education and its relation with the 
economic growth and a direct relationship was found between the two. The study also found that school education shows good results both in the short run and long run.

Akram (2008) in his paper explained that education gets most of the attention in human capital and there is less work done on health care and its effects on the economic growth. It plays a very strong role in national output as labour force is correlated to it. After realization focus was set on health and its impacts on the economy. When there is a developed heath sector it increases the life expectancy in that region and also reduces the deaths at birth. With the reports of World Bank it does conform that good health measures increases the life expectancy. Then the focus is shifted towards Pakistan and explains that health care was never their priority and due to that reason Pakistan always ranks very low among all countries on the human development index. A less work done was only restricted to urban areas. The first result showed that there is a positive relationship between health expenditure and GDP. The other result showed negative relationship of fertility rate with the economic growth.

Khan (2005) explains that there are several determinants of economic growth which can help in a country's development but education and health play most important roles. He said that Pakistan is economically growing at a very good speed as compared to other developing nations but there are some countries in South Asia which are much more developed. He also focused on the improvement of institutions as they give better results in the long run.

Abbas and Nasir (2001) in their paper did a comparison between Pakistan and Sri Lanka on their human capital and economic growth and found a positive relationship between the two in the long run but negative relationship in the short run. This is because the population is increasing constantly in the developing countries. The necessity for primary education should be fulfilled with time due to its constant demand and as it is the first step towards education, more importance should be given to it.

Al-Yousif (2008) investigated the relationship between education expenditure and economic growth in six Gulf cooperation countries. He believed that education expenditure is the real contributor in economic growth and in every economy human capital plays a vital role in which education acts as an input just like factors of production. The results showed that every country has its own reasons for economic growth and that human capital variables cannot be standardized across all countries.

Qadri and Abdul Waheed (2011) found similar conclusion in the context of Pakistan using time series data for 30 years time period. He concluded that human capital has a positive relationship with economic growth and that education has an important role in building human capital. Therefore, the government should pay 
more attention on education and health care.

Shehzad (2004) attempted to identify mortality reducing techniques which were used by countries lower in per capita income than Pakistan. He concluded that there are many reasons for Pakistan's abnormal higher infant mortality rate. This problem can be solved through a simple method of educating women which can reduce the infant and child mortality rates.

Amjad (2005), in his study on the cotton industry of Pakistan, investigated the relationship between human capital and economic growth. He concluded that our workers need education and new skills if they want the industry to grow and compete in the international market. The industry will not prosper if they continue to work with the same techniques, old equipment, and unskilled labour. They need to understand the importance of physical capital and the impact it can have on the overall growth of the economy.

Ali, Farooq, and Chaudhry (2011) in their paper explained the importance of relationship between human capital and economic growth. He said that more focus was given to physical capital rather than education and health care due to which less economic output is seen. The paper took different variables like CPI inflation, infant mortality rate, and gross fixed capital formation and all showed positive relationship with economic growth in the long run.

Mehraha and Musai (2013) in their paper investigated the relationship between education and economic growth as education produces a multiplier effect in the economic growth. Result showed a strong relationship between education and economic growth.

\section{Methodology}

To investigate the relationship between human capital and economic growth, different variables can be used. For measuring education, the study uses one category of primary enrolment, whereas for health, two indicators are used, i.e. infant mortality rate and birth rate. Physical capital is used as another independent variable. The data is taken from 1972 to 2013.

\subsection{Description of Variables}

\subsubsection{Gross Domestic Product (GDP)}

It calculates the overall production of goods and services in a country in a given year. It is a gauge of economic growth of a country. In this study, GDP per capita acts 
as a dependent variable. This proxy is borrowed from Afzal (2010) and Akram (2008).

\subsubsection{Primary Enrolments (EDU)}

It is measured by the ratio of total number of students enrolled in primary schools divided by total population of that age bracket ( 5 to 10 years). This proxy is borrowed from Mehrara (2013) and Al-Yousif (2008).

\subsubsection{Infant Mortality Rate (IMR)}

It is measured as the number of infant deaths per 1000 births. Infant mortality rate is the proxy for health which we have borrowed from Shehzad (2004) and Ali et al. (2012).

\subsubsection{Birth Rate (BR)}

Birth rate is the second proxy for health and is measured as the number of births per 1000 people of the population. This proxy is borrowed from Akram (2008).

\subsubsection{Physical Capital (PC)}

It represents the factors of production. Physical Capital is also known as fixed capital formation. We have borrowed proxy for this variable from Abbas and Foreman-Peck (2008) and Iqbal (2009).

\subsection{Empirical Model}

To find the long term relationship between human capital and economic growth, co-integration test is used. The method used by most of the researchers in literature is Autoregressive Distributive Lag (ARDL) approach to Co-integration, presented as under.

\subsubsection{Auto Regressive Distributed Lag (ARDL) Model}

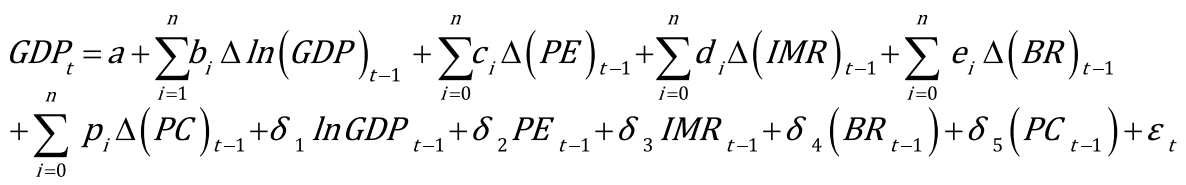

\subsection{Data Source}

The data for education, health, physical capital and gross domestic product is taken from the 'Pakistan' profile on the World Bank website. 


\section{Analysis}

\subsubsection{Unit Root Test}

The test which is supported by the literature is Augmented Dickey Fuller test and has been used by Afzal (2010), Akram (2008), Mohsin (2005), Abbas (2001), Amjad (2005) and Ali et al. (2012). Table 1 shows the results of unit root test.

Table 1: Unit root test for variables

\begin{tabular}{|c|c|c|c|c|}
\hline Variables & T Statistic & Critical Value & P-Value & Integrated Order \\
\hline GDP & -4.870890 & -2.935001 & 0.0003 & I_1 \\
\hline PE & -6.346135 & -2.936942 & 0.0000 & I_1 \\
\hline IMR & -3.105507 & -2.943427 & 0.0348 & I_0 \\
\hline BR & -3.087377 & -2.948404 & 0.0368 & I_0 \\
\hline PC & -6.022784 & -2.936942 & 0.0000 & I_1 \\
\hline
\end{tabular}

Since the p-value for all the variables is greater than the level of significance, it is concluded that the variables data are stationary, either at level or at first difference.

\subsection{Bound Test}

Table 2 presents results of the Bound test which investigates the long run relationship between the dependent and independent variables. Since the p-value of the chi-square test is less than the level of significance, we reject our null hypothesis and conclude that there is a long-term relationship between the variables.

Table 2: Bound test

\begin{tabular}{|c|c|c|c|}
\hline \multicolumn{4}{|c|}{ Wald Test: } \\
\hline Test Statistic & Value & Df & Probability \\
\hline F-statistic & 8.651382 & $(11,28)$ & 0.0000 \\
\hline Chi-square & 95.16520 & 11 & 0.0000 \\
\hline
\end{tabular}

\subsection{Results of the ARDL Model}

Table reports results of the ARDL model. The value of Durbin Watson is 2 shows the absence of autocorrelation. The value of R-squared is 0.54 which shows that 54 percent of the changes occurring in the dependent variable is because of independent variables, the rest being due to residual term. ARDL results also show that if the birth rate increases by 1 percent, it will increase GDP by 6.14 percent. Birth rate and GDP 
have a positive relationship. One percent increase in infant mortality rate will decrease GDP by 27 percent. IMR has a very significant impact on the GDP. Primary enrolment also has a negative impact on GDP. One percent increase in PE will decrease GDP by 17 percent. One percent increase in physical capital will increase GDP by 7 percent.

Table 3: Results of the ARDL model

\begin{tabular}{|c|c|c|c|c|}
\hline Variable & Coefficient & Std. Error & t-Statistic & Prob. \\
\hline GDP(-1) & -1.082621 & 0.209616 & -5.164775 & 0.0000 \\
\hline LBR(-1) & 6.148592 & 9.048492 & 0.679516 & 0.5024 \\
\hline LIMR(-1) & -27.79802 & 8.193301 & -3.392774 & 0.0021 \\
\hline LPE(-1) & -17.93720 & 8.530926 & -2.102609 & 0.0446 \\
\hline LPC(-1) & 7.526224 & 3.596654 & 2.092563 & 0.0456 \\
\hline $\begin{array}{c}\text { Long Run D(G- } \\
\text { DP(-1)) }\end{array}$ & 0.030951 & 0.136747 & 0.226341 & 0.8226 \\
\hline D(LBR(-1)) & -21.09798 & 71.49312 & -0.295105 & 0.7701 \\
\hline D(LIMR(-1)) & 677.8082 & 282.1503 & 2.402295 & 0.0232 \\
\hline D(LPE(-1)) & 12.78596 & 6.625652 & 1.929766 & 0.0638 \\
\hline D(LPC(-1)) & 9.897547 & 3.694451 & 2.679031 & 0.0122 \\
\hline C & 217.7219 & 68.60682 & 3.173474 & 0.0036 \\
\hline R-squared & 0.549372 & \multicolumn{2}{|c|}{ Durbin-Watson stat } & 2.018759 \\
\hline
\end{tabular}

\subsection{Vector Error Correction Model}

"Results of the VECM model are reported in Table 4. Theoretically, the error correction coefficient of VECM should be negative and statistically significant for the variable of interest in order to adjust towards the equilibrium. The error correction coefficient for GDP is -0.4193 , which means that in case of disequilibrium the dependent variable will go to its equilibrium level by the rate of $41.93 \%$ in one period. The coefficient value of 0.4193 shows the speed of adjustment of the variables in the model. 
Table 4: Vector Error Correction Model

\begin{tabular}{|c|c|c|c|c|c|}
\hline $\begin{array}{c}\text { Co integrating } \\
\text { Eq: }\end{array}$ & CointEq1 & & & & \\
\hline GDP(-1) & 1.000000 & & & & \\
\hline \multirow[t]{3}{*}{$\operatorname{LBR}(-1)$} & -53.49262 & & & & \\
\hline & $(11.0078)$ & & & & \\
\hline & [-4.85953] & & & & \\
\hline \multirow[t]{3}{*}{ LIMR(-1) } & 78.04910 & & & & \\
\hline & $(7.58939)$ & & & & \\
\hline & [ 10.2840] & & & & \\
\hline \multirow[t]{3}{*}{ LPC(-1) } & 40.61961 & & & & \\
\hline & $(3.24473)$ & & & & \\
\hline & [ 12.5186] & & & & \\
\hline \multirow[t]{3}{*}{ LPE(-1) } & 15.69368 & & & & \\
\hline & $(6.99933)$ & & & & \\
\hline & [ 2.24217] & & & & \\
\hline C & -354.7132 & & & & \\
\hline Error Correction: & $\mathrm{D}(\mathrm{GDP})$ & $\mathrm{D}(\mathrm{LBR})$ & D(LIMR) & $\mathrm{D}(\mathrm{LPC})$ & $\mathrm{D}(\mathrm{LPE})$ \\
\hline \multirow[t]{3}{*}{ CointEq1 } & -0.419358 & -0.000327 & $4.89 \mathrm{E}-05$ & -0.006094 & -0.000588 \\
\hline & $(0.15760)$ & $(4.3 \mathrm{E}-05)$ & $(6.6 \mathrm{E}-05)$ & $(0.00503)$ & $(0.00274)$ \\
\hline & {$[-2.66086]$} & {$[-7.60343]$} & [0.74238] & {$[-1.21062]$} & {$[-0.21478]$} \\
\hline \multirow[t]{3}{*}{$\mathrm{D}(\mathrm{GDP}(-1))$} & -0.437497 & 0.000227 & $3.69 \mathrm{E}-05$ & 0.014908 & -0.002817 \\
\hline & $(0.18416)$ & $(5.0 \mathrm{E}-05)$ & $(7.7 \mathrm{E}-05)$ & $(0.00588)$ & $(0.00320)$ \\
\hline & {$[-2.37569]$} & [ 4.50510] & [ 0.47860$]$ & [ 2.53467] & {$[-0.88012]$} \\
\hline \multirow[t]{3}{*}{$\mathrm{D}(\mathrm{GDP}(-2))$} & -0.150433 & 0.000155 & 0.000177 & 0.017248 & -0.003148 \\
\hline & $(0.16659)$ & $(4.5 \mathrm{E}-05)$ & $(7.0 \mathrm{E}-05)$ & $(0.00532)$ & $(0.00289)$ \\
\hline & {$[-0.90303]$} & [ 3.40890] & [ 2.53758] & [ 3.24179] & {$[-1.08738]$} \\
\hline \multirow[t]{3}{*}{$\mathrm{D}(\mathrm{LBR}(-1))$} & 96.21651 & 1.723105 & 0.056063 & 2.348984 & 4.270789 \\
\hline & $(175.334)$ & $(0.04789)$ & $(0.07333)$ & (5.59976) & $(3.04686)$ \\
\hline & [0.54876] & [ 35.9837] & [0.76449] & [ 0.41948] & [ 1.40170] \\
\hline \multirow[t]{3}{*}{ D(LBR(-2)) } & -220.4100 & -0.896124 & -0.022825 & -0.872914 & -4.737653 \\
\hline & $(162.290)$ & $(0.04432)$ & $(0.06788)$ & (5.18314) & (2.82018) \\
\hline & {$[-1.35813]$} & {$[-20.2180]$} & {$[-0.33626]$} & {$[-0.16841]$} & {$[-1.67991]$} \\
\hline
\end{tabular}




\begin{tabular}{|c|c|c|c|c|c|}
\hline \multirow[t]{3}{*}{ D(LIMR(-1)) } & 1035.184 & 0.711041 & 1.116377 & 15.47810 & -6.171077 \\
\hline & $(533.436)$ & $(0.14569)$ & $(0.22311)$ & $(17.0367)$ & $(9.26976)$ \\
\hline & [ 1.94059$]$ & [ 4.88060] & [ 5.00368] & [ 0.90852] & {$[-0.66572]$} \\
\hline \multirow[t]{3}{*}{ D(LIMR(-2)) } & -57.07544 & 0.105908 & -0.359901 & -11.95606 & 6.345433 \\
\hline & $(487.324)$ & (0.13309) & $(0.20382)$ & $(15.5640)$ & $(8.46843)$ \\
\hline & {$[-0.11712]$} & [ 0.79574$]$ & [-1.76574] & {$[-0.76819]$} & [ 0.74930$]$ \\
\hline \multirow[t]{3}{*}{$\mathrm{D}(\mathrm{LPC}(-1))$} & 6.753583 & 0.011597 & 0.000940 & 0.045402 & -0.061322 \\
\hline & $(7.45074)$ & $(0.00203)$ & $(0.00312)$ & $(0.23796)$ & $(0.12947)$ \\
\hline & [ 0.90643$]$ & [ 5.69931] & [ 0.30153$]$ & [ 0.19080] & [-0.47362] \\
\hline \multirow[t]{3}{*}{$\mathrm{D}(\mathrm{LPC}(-2))$} & 0.521049 & 0.005375 & 0.001797 & 0.226188 & 0.075942 \\
\hline & $(7.00283)$ & $(0.00191)$ & $(0.00293)$ & $(0.22365)$ & $(0.12169)$ \\
\hline & [ 0.07441$]$ & [ 2.81014] & [ 0.61337] & [ 1.01133] & [ 0.62405$]$ \\
\hline \multirow[t]{3}{*}{$\mathrm{D}(\operatorname{LPE}(-1))$} & 11.24353 & 0.002422 & -0.000572 & 0.280203 & -0.099558 \\
\hline & $(12.6786)$ & $(0.00346)$ & $(0.00530)$ & $(0.40492)$ & $(0.22032)$ \\
\hline & [ 0.88681$]$ & [ 0.69937] & [-0.10789] & [ 0.69199] & [-0.45188] \\
\hline \multirow[t]{3}{*}{$\mathrm{D}(\operatorname{LPE}(-2))$} & 0.540052 & 0.002105 & -0.002442 & 0.022630 & 0.073394 \\
\hline & $(11.9260)$ & $(0.00326)$ & $(0.00499)$ & $(0.38089)$ & $(0.20724)$ \\
\hline & [ 0.04528$]$ & [ 0.64614] & {$[-0.48960]$} & [ 0.05941$]$ & [ 0.35415$]$ \\
\hline \multirow[t]{3}{*}{$\mathrm{C}$} & 14.23557 & 0.010932 & -0.003583 & 0.075466 & 0.013301 \\
\hline & $(5.68427)$ & $(0.00155)$ & $(0.00238)$ & $(0.18154)$ & $(0.09878)$ \\
\hline & [ 2.50438] & [ 7.04170] & {$[-1.50723]$} & [ 0.41569$]$ & [ 0.13465$]$ \\
\hline R-squared & 0.511019 & 0.998386 & 0.953270 & 0.382010 & 0.213411 \\
\hline Adj. R-squared & 0.311805 & 0.997729 & 0.934232 & 0.130236 & -0.107052 \\
\hline Sum sq. residuals & 103.8717 & $7.75 \mathrm{E}-06$ & $1.82 \mathrm{E}-05$ & 0.105950 & 0.031367 \\
\hline S.E. equation & 1.961402 & 0.000536 & 0.000820 & 0.062643 & 0.034084 \\
\hline F-statistic & 2.565174 & 1518.488 & 50.07143 & 1.517276 & 0.665946 \\
\hline Log likelihood & -74.44069 & 245.5790 & 228.9569 & 59.87416 & 83.61002 \\
\hline Akaike AIC & 4.432856 & -11.97841 & -11.12599 & -2.455085 & -3.672309 \\
\hline Schwarz SC & 4.944721 & -11.46655 & -10.61413 & -1.943220 & -3.160444 \\
\hline Mean dependent & 0.015380 & -0.013280 & -0.016440 & 0.002199 & 0.014559 \\
\hline S.D. dependent & 2.364345 & 0.011240 & 0.003199 & 0.067169 & 0.032394 \\
\hline
\end{tabular}




\section{Conclusion}

This paper confirms the results of current literature and theories by showing positive relationship of human capital and economic growth in Pakistan for the time period 1972 to 2013. This result is achieved using ARDL and VECM models. The results show that physical capital and birth rate have positive impact on the economic growth. Empirical evidence also proves that the human capital plays an important role in the prosperity of a nation. These results are not effective in the short run but need investment in the short to have better outcomes in the long run. Sooner the spending, the more healthy and educated people will serve the country in the short run. To achieve this, a lot of consideration is essential for health and education sectors. The allocation of budget needs to get revised and shift focus towards the core elements of a good economy by investing in health and education.

\section{References}

Al-Yousif, Y. K. (2008). Education expenditure and economics growth: Some empirical evidence from the GCC countries. The Journal of Developing Areas, 42(1), 69-80.

Abbas, Q., \& Nasir, Z. M. (2001). Endogenous growth and human capital: A comparative study of Pakistan and Sri Lanka. The Pakistan Development Review, 39(4), 451-473.

Khan, M. (2005) Human Capital and economics growth in Pakistan (Distinguished Lecture). The Pakistan Development Review, 44(4), 445-478.

Akram, N. (2008). The long term Impact of health on economic growth in Pakistan. The Pakistan Development Review, 47(4), 487-500.

Afzal, M. (2010). Relationship between school education and economic growth in Pakistan: ARDL bounds testing approach to cointegration. Pakistan Economic and Social Review, 48(1), 39-60.

Amjad, R. (2005). Skills and competitiveness: Can Pakistan break out of the low-level skills trap? The Pakistan Development Review, 44(4), 387-409.

Qadri, F. S., \& Abdul Waheed, W. (2011). Human capital and economic growth: Time series evidence from Pakistan. Pakistan Business Review, 1, 815-833

Mehrara, M., \& Musai, M. (2013). The relationship between economic growth and human capital in developing countries. International Letters of Social and Humanistic Sciences, 5, 55-62.

Abbas, Q., \& Foreman-Peck, J. S. (2008). Human capital and economic growth: Pakistan 1960-2003. Lahore Journal of Economics, 13(1), 1-27.

Ali, S., Farooq, F., \& Chaudhry, I. S. (2012). Human capital formation and economic growth in Pakistan. Pakistan Journal of Social Sciences, 32(1), 229-240.

Shehzad, S. (2004). How Can Pakistan Reduce Infant and Child Mortality Rates? A Decomposition Analysis. Sustainable Development Policy Institute. 